\title{
Analysis of the Influence of Consumer Perception, Innovation and Product Quality on Purchasing Decisions of Travelers Consuming Traditional Getuk Goreng Foods in the Middle Sokaraja Village Sokaraja District
}

\author{
Elizabeth Tika Kristina Hartuti ${ }^{1}$, Cornelia Dumarya Manik ${ }^{2}$ \\ 1,2 Universitas Pamulang \\ E-mail: dosen01503@unpam.ac.id
}

\begin{abstract}
The company tries to create a product of course with good quality so consumers are interested in buying the product being sold. This study aims to determine the effect of consumer perceptions, innovation and product quality on purchasing decisions of tourists consuming traditional getuk goreng food in Sokaraja Tengah Village, Sokaraja District. The method used was explanatory research with a sample of 96 respondents. The analysis technique uses instrument testing, classical assumption test, regression testing, correlation coefficient, coefficient of determination and hypothesis testing. The results of this study consumers' perceptions significantly influence purchasing decisions by $31.9 \%$, hypothesis testing obtained significance $0,000<0.05$. Innovation has a significant effect on purchasing decisions by $41.4 \%$, hypothesis testing obtained significance $0,000<0.05$. Product quality has a significant effect on purchasing decisions by $26.9 \%$, hypothesis testing obtained significance $0,000<0.05$. Consumer perception, innovation and product quality simultaneously have a significant effect on purchasing decisions by $50.1 \%$, the hypothesis test obtained significance of $0,000<0.05$. Purchasing decisions significantly influence consumer satisfaction by $45.5 \%$, hypothesis testing obtained significance 0,000 $<0.05$.
\end{abstract}

Keywords: consumer perception; innovation; product quality; purchasing decisions.

\section{INTRODUCTION}

The role of the industrial sector is quite important in Indonesia. The Industrial Sector still contributes significantly to national economic growth (Jackson, 2014; John L. Colley, Doyle, Hardie, Logan, \& Stettinius, 2007; Novicadisa \& Sjamsuddin, 2016; Soliha, 2008; Wibawa, Rahmawati, \& Rainaldo, 2007 2018). The government is mandated to take the role and support of the distribution and distribution of industries by preparing Provincial and Regency / City Industrial Development plans that refer to the National Industrial Development Master Plan and National Industrial Policy. Apart from industrial distribution, the industrial sector still has constraints related to competitiveness and productivity. The development in the tourism sector was also increased by the government, especially the regional government, so that the potential of each region can develop and will increase local income (Kadji, 2015; Prasodjo, 2017; Said, Akib, Salam, \& Baharuddin, 2017; Samad, Salim, Arfin, \& Akib, 2018).

Indonesia has great potential in various aspects including cultural aspects. Almost all regions in Indonesia have distinctive regional characteristics including traditional food (Chandra, 2016; Sabana, 2007; Yusa \& Suter, 2012). By having the characteristics of a 


\author{
2 Jurnal Administrare: Jurnal Pemikiran Ilmiah dan Pendidikan Administrasi Perkantoran \\ Vol. 7, No. 1, January-June 2020, Pages 1-10
}

traditional food area, it is expected to be able to attract tourists to visit, for example in the Sokaraja District of Banyumas Regency with the production of various traditional foods. Sokaraja sub-district is located in Banyumas Regency, Central Java Province. In Sokaraja Subdistrict, it is divided into 18 villages, namely Kalikidang, Wiradadi, Karangkedawung, Middle Sokaraja, Sokaraja Kidul, Klahang, Banjarsari Kidul, Sokaraja Wetan, Jompo Kulon, Banjaranyar, Lemberang, Karangduren, Sokaraja Lor, Kedondong, Pamijen, Sokaraja Kidul, Sokaraja Wetan, Jompo Kulon, Banjaranyar, Lemberang, Karangduren, Sokaraja Lor, Kedondong, Pamijen, Sokaraja Kidul, Sokaraja Wetan, Jompo Kulon, Banjaranyar, Lemberang, Karangduren, Sokaraja Lor, Kedondong, Pamijen, Sokaraja Kidul, Sokaraja Wetan, Jompo Kulon, Banjaranyar, Lemberang, Karangduren, Sokaraja Lor, Kedondong, Pamijen, Sokaraja Kidon. The center for fried souvenir is found in the village of Central Sokaraja.

Traditional food is food that is commonly eaten for generations, consisting of dishes that are suitable to taste, are not in conflict with religion, the beliefs of the local community and are made from food ingredients and spices available in the local area (D'Antuono, 2015; Rahmawaty \& Maharani, 2014; Sims, 2009). Traditional food products that have the Sokaraja District for example tempe chips, jenang, klanting, fried getuk, etc. One of the variables discussed in this study is perception. With a good perception from tourists, it is expected to be able to encourage tourists to buy traditional food in the village of Central Sokaraja. In current consumer behavior consumer perception is very important because the better perception of consumers is expected to influence the purchase decision on a product.

Every company must create innovations that will help / support efforts to improve or maintain the position of the product in its target market (Lendel, Hittmár, \& Siantová, 2015; Wairooy, 2017). Innovation is a main tool to achieve certain product positions in carrying out the expected functions. The company tries to create a product of course with good quality so consumers are interested in buying the product being sold. With a good quality product the consumer will decide to buy the product. Product quality is an important thing that must be sought by every company if they want the products produced can compete in the market. According to (Kotler and Armstrong, 2008) that the better the quality of the product produced will provide an opportunity for consumers to make purchasing decisions.

A consumer in the process of making a purchase decision does not only end with a purchase transaction, but is also followed by the stage of post-purchase behavior. If the consumer is satisfied, he will show a great opportunity to repurchase or buy another product in the same company in the future (Sunyoto, 2014; Sutisna, 2003; Swastha, Basu, 2014; Tjiptono, 2007).

\title{
METHOD
}

The type of research used is associative, where the aim is to find out the connection between. The population in this study amounted to 96 respondents Tourists consume traditional getuk goreng food in the Middle Sokaraja Village, Sokaraja District. The sampling technique in this study is saturated sampling, where all members of the population are sampled. Thus the sample in this study amounted to 96 respondents. In analyzing the data used the instrument test, classical assumption test, regression, coefficient of determination and hypothesis testing. 


\section{RESULT AND DISCUSSION}

Purchasing decisions are a series of processes that consumers go through in deciding the purchase action. The purchasing decision indicators are: the purpose of buying the product, the information process, product maturity, recommending and repurchasing.

\section{Descriptive Analysis}

In this test used to determine the highest minimum and maximum scores, ratting scores and standard deviations of each variable. The results are presented in table 1.

\section{Table 1}

\section{Statistical Descriptive Analysis Results}

\section{Descriptive Statistics}

\begin{tabular}{l|r|r|r|r|r}
\hline & $\mathrm{N}$ & Minimum & Maximum & Mean & Std. Deviation \\
\hline Consumer Perception (X1) & 96 & 28 & 46 & 38.03 & 3.754 \\
\hline Innovation (X2) & 96 & 31 & 46 & 37.78 & 3.859 \\
\hline Product Quality (X3) & 96 & 31 & 48 & 38.04 & 3.656 \\
\hline Purchase Decision (Y) & 96 & 28 & 47 & 38.55 & 3.627 \\
\hline Valid N (listwise) & 96 & & & & \\
\hline
\end{tabular}

Consumer perception obtained a minimum variance of 28 and a maximum variance of 46 with a ratting score of 3.803 with a standard deviation of 3.764. Innovations obtained a minimum variance of 31 and a maximum variance of 46 with a ratting score of 3.778 with a standard deviation of 3.859. Product quality obtained a minimum variance of 31 and a maximum variance of 48 with a ratting score of 3.804 with a standard deviation of 3.656. The purchase decision obtained a minimum variance of 28 and a maximum variance of 47 with a ratting score of 3.855 with a standard deviation of 3.627 .

\section{Multiple Regression Analysis}

This regression test is intended to determine changes in the dependent variable if the independent variable changes. The test results are in table 2.

\section{Table 2}

\section{Multiple Regression Testing Results}

\begin{tabular}{|c|c|c|c|c|c|}
\hline \multirow[b]{3}{*}{ Model } & \multicolumn{2}{|c|}{ Coefficients $^{\mathrm{a}}$} & \multirow{3}{*}{$\begin{array}{c}\text { Standardized } \\
\text { Coefficients } \\
\text { Beta }\end{array}$} & \multirow[b]{3}{*}{$\mathrm{t}$} & \multirow[b]{3}{*}{ Sig. } \\
\hline & \multicolumn{2}{|c|}{$\begin{array}{l}\text { Unstandardized } \\
\text { Coefficients }\end{array}$} & & & \\
\hline & $\mathrm{B}$ & Std. Error & & & \\
\hline $\begin{array}{ll}1 & \text { (Constant) }\end{array}$ & 7.564 & 3.331 & & 2.271 & .025 \\
\hline Consumer Perception (X1) & .233 & .090 & .241 & 2.600 & .011 \\
\hline Innovation $(\mathrm{X} 2)$ & .366 & .092 & .390 & 3.996 & .000 \\
\hline Product Quality (X3) & .218 & .086 & .219 & 2.528 & .013 \\
\hline
\end{tabular}

a. Dependent Variable: Purchase Decision (Y) 
4 Jurnal Administrare: Jurnal Pemikiran Ilmiah dan Pendidikan Administrasi Perkantoran

Vol. 7, No. 1, January-June 2020, Pages 1-10

Based on the test results in the above table, the regression equation $\mathrm{Y}=7,564+0,233 \mathrm{X} 1$ $+0,366 \mathrm{X} 2+0,218 \mathrm{X} 3$ is obtained. A constant of 7,564 means if there is no consumer perception and innovation, then there is a purchase decision value of 7,564 points. Regression coefficient of consumer perception by 0.233 , this number is positive meaning that every time there is an increase in consumer perception by 0.233 , the purchasing decision will also increase by 0.233 points. Innovation regression coefficient of 0.366 , this number is positive, meaning that every time there is an increase in innovation of 0.366 , the purchasing decision will also increase by 0.366 points. Product quality regression coefficient of 0.218 , this number is positive, meaning that every time there is an increase in product quality by 0.218 , the purchasing decision will also increase by 0.218 points.

\section{Correlation Coefficient Analysis}

Correlation coefficient analysis is intended to determine the degree of relationship strength of the independent variables on the dependent variable either partially or simultaneously. The test results are as follows:

Table 3

Test Results Correlation Coefficient Consumer Perception of Purchasing Decisions. Correlations $^{\text {b }}$

\begin{tabular}{llrrr}
\hline & & $\begin{array}{l}\text { Consumer } \\
\text { Perception (X1) }\end{array}$ & \multicolumn{1}{l}{$\begin{array}{l}\text { Purchasing } \\
\text { Decisions (Y) }\end{array}$} \\
\hline Consumer Perception (X1) & Pearson Correlation & 1 & $.565^{* *}$ \\
\cline { 2 - 4 } & Sig. (2-tailed) & & .000 \\
\hline Purchase Decision (Y) & Pearson Correlation & $.565^{* *}$ & 1 \\
\cline { 2 - 4 } & Sig. (2-tailed) & .000 & \\
\hline \multirow{2}{*}{$\begin{array}{l}\text { **. Correlation is significant at the 0.01 level (2-tailed). } \\
\text { b. Listwise N=96 }\end{array}$} & & &
\end{tabular}

Based on the test results obtained by a correlation value of 0.565 means that consumer perceptions have a moderate relationship to purchasing decisions.

Table 4

Test Results for Innovation Correlation Coefficient on Purchasing Decisions.

Correlations $^{\mathbf{b}}$

\begin{tabular}{llr|r}
\hline & & \multicolumn{2}{c}{$\begin{array}{c}\text { Purchasing } \\
\text { Decisions (Y) }\end{array}$} \\
\hline Inovation (X2) & Pearson Correlation & 1 & $.644^{* *}$ \\
\cline { 2 - 4 } & Sig. (2-tailed) & & .000 \\
\hline Purchase Decision (Y) & Pearson Correlation & $.644^{* *}$ & 1 \\
\cline { 2 - 4 } & Sig. (2-tailed) & .000 & \\
\hline
\end{tabular}

**. Correlation is significant at the 0.01 level (2-tailed).

b. Listwise $\mathrm{N}=96$ 
Based on the test results obtained a correlation value of 0.644 means that innovation has a strong relationship with purchasing decisions.

Table 5

Correlation Coefficient Test Results for Product Quality on Purchasing Decisions. Correlations $^{\mathrm{b}}$

\begin{tabular}{llr|r}
\hline & & $\begin{array}{r}\text { Product quality } \\
\text { (X3) }\end{array}$ & $\begin{array}{r}\text { Purchasing } \\
\text { Decisions (Y) }\end{array}$ \\
\hline Product quality (X3) & Pearson Correlation & 1 & $.519^{* *}$ \\
\cline { 2 - 4 } & Sig. (2-tailed) & $.519^{* *}$ & .000 \\
\hline Purchasing Decisions (Y) & Pearson Correlation & .000 & 1 \\
\cline { 2 - 4 } & Sig. (2-tailed) & & \\
\hline \multirow{2}{**}{$\begin{array}{l}\text { ** Correlation is significant at the 0.01 level (2-tailed). } \\
\text { b. Listwise N=96 }\end{array}$} & &
\end{tabular}

Based on the test results obtained a correlation value of 0.519 means that the quality of the product has a moderate relationship to the purchasing decision.

Table 6

Test Results Correlation Coefficient of Consumer Perception, Product Quality and Simultaneous Innovation of Purchasing Decisions.

Model Summary

\begin{tabular}{|c|c|c|c|c|}
\hline Model & $\mathrm{R}$ & R Square & $\begin{array}{l}\text { Adjusted R } \\
\text { Square }\end{array}$ & $\begin{array}{l}\text { Std. Error of the } \\
\text { Estimate }\end{array}$ \\
\hline 1 & $.708^{\mathrm{a}}$ & .501 & .485 & 2.604 \\
\hline
\end{tabular}

Based on the test results obtained by the correlation value of 0.708 means that consumer perception, innovation and product quality simultaneously have a strong relationship to purchasing decisions.

\section{Analysis of the Coefficient of Determination}

Analysis of the coefficient of determination is intended to determine the percentage of influence of the independent variable on the dependent variable either partially or simultaneously. The test results are as follows:

Table 7

Test Results for the Consumer Perception Determination Coefficient on Purchasing Decisions.

Model Summary

\begin{tabular}{lc|r|r|r}
\hline Model & R & R Square & Adjusted R Square & Std. Error of the Estimate \\
\hline 1 & $.565^{\text {a }}$ & .319 & .312 & 3.009 \\
\hline \multicolumn{2}{rl}{ a. Predictors: (Constant), Persepsi Konsumen (X1) }
\end{tabular}


6 | Jurnal Administrare: Jurnal Pemikiran Ilmiah dan Pendidikan Administrasi Perkantoran
Vol. 7, No. 1, January-June 2020, Pages 1-10

Based on the test results obtained a determination value of 0.319 means that consumer perceptions have a contribution of $31.9 \%$ influence on purchasing decisions.

Table 8

Test Results for the Innovation Determination Coefficient on Purchasing Decisions. Model Summary

\begin{tabular}{|c|c|c|c|c|}
\hline Model & $\mathrm{R}$ & R Square & $\begin{array}{l}\text { Adjusted R } \\
\text { Square }\end{array}$ & $\begin{array}{l}\text { Std. Error of the } \\
\text { Estimate }\end{array}$ \\
\hline 1 & $.644^{\mathrm{a}}$ & .414 & .408 & 2.79 \\
\hline
\end{tabular}

a. Predictors: (Constant), Inovation (X2)

Based on the test results obtained a determination value of 0.414 means that innovation has an influence contribution of $41.4 \%$ to the purchase decision.

Table 9

Test Results for the Determination of Product Quality Coefficient on Purchasing Decisions.

Model Summary

\begin{tabular}{|c|c|c|c|c|}
\hline Model & $\mathrm{R}$ & R Square & $\begin{array}{l}\text { Adjusted R } \\
\text { Square }\end{array}$ & $\begin{array}{l}\text { Std. Error of the } \\
\text { Estimate }\end{array}$ \\
\hline 1 & $.519^{\mathrm{a}}$ & .269 & .262 & 3.11 \\
\hline
\end{tabular}

a. Predictors: (Constant), Product Quality (X3)

Based on the test results obtained a determination value of 0.269 means that product quality has an influence contribution of $26.9 \%$ on purchasing decisions.

Table 10

Test Results Determination Coefficient of Consumer Perception, Innovation and Product Quality on Purchasing Decisions.

Model Summary

\begin{tabular}{|c|c|c|c|c|}
\hline \multicolumn{5}{|c|}{ Model Summary } \\
\hline Model & $\mathrm{R}$ & R Square & $\begin{array}{c}\text { Adjusted R } \\
\text { Square }\end{array}$ & $\begin{array}{l}\text { Std. Error of the } \\
\text { Estimate }\end{array}$ \\
\hline 1 & $.708^{\mathrm{a}}$ & .501 & .485 & 2.604 \\
\hline
\end{tabular}

a. Predictors: (Constant), Product Quality (X3), Innovation (X2), Consumer Perception (X1)

Based on the test results obtained a determination value of 0.501 means that consumer perception, innovation and product quality simultaneously have an influence contribution of $50.1 \%$ on purchasing decisions, while the remaining $49.9 \%$ is influenced by other factors.

\section{Hypothesis testing}

Hypothesis testing with $\mathrm{t}$ test is used to find out which partial hypotheses are accepted. 
Table 11.

Results of the Consumer Perception Hypothesis Test on Purchasing Decisions.

Coefficients $^{\mathbf{a}}$

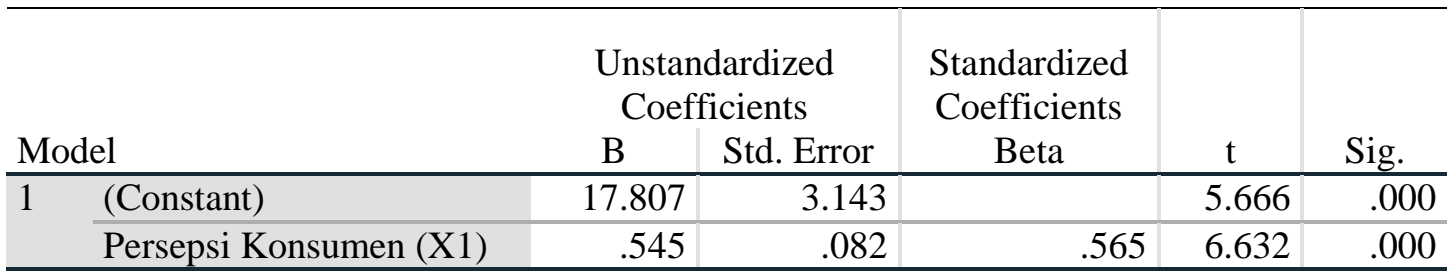

a. Dependent Variable: Purchasing Decisions (Y)

Based on the test results in the above table, $t_{\text {count }}>t_{\text {table }}$ or $(6.632>1.986)$ is obtained, thus the hypothesis proposed that there is a significant influence between consumers' perceptions of purchasing decisions is accepted.

Table 12.

Results of the Innovation Hypothesis Test on Purchasing Decisions.

Coefficients $^{\mathrm{a}}$

\begin{tabular}{|c|c|c|c|c|c|}
\hline \multirow[b]{2}{*}{ Model } & \multicolumn{2}{|c|}{$\begin{array}{l}\text { Unstandardized } \\
\text { Coefficients }\end{array}$} & \multirow{2}{*}{$\begin{array}{l}\text { Standardized } \\
\text { Coefficients } \\
\text { Beta }\end{array}$} & \multirow[b]{2}{*}{$\mathrm{t}$} & \multirow[b]{2}{*}{ Sig. } \\
\hline & B & Std. Error & & & \\
\hline $\begin{array}{ll}1 & \text { (Constant) }\end{array}$ & 15.698 & 2.818 & & 5.570 & .000 \\
\hline Inovasi (X2) & .605 & .074 & 644 & 8.151 & .000 \\
\hline
\end{tabular}

a. Dependent Variable: Purchasing Decisions (Y)

Based on the test results in the above table, $t_{\text {count }}>t_{\text {table }}$ or $(8,151>1,986)$ is obtained, thus the hypothesis proposed that there is a significant influence between innovation on purchasing decisions is accepted.

Table 13

Hypothesis Test Results for Product Quality on Purchasing Decisions

Coefficients $^{\mathrm{a}}$

\begin{tabular}{|c|c|c|c|c|c|}
\hline \multirow[b]{2}{*}{ Model } & \multicolumn{2}{|c|}{$\begin{array}{l}\text { Unstandardized } \\
\text { Coefficients }\end{array}$} & \multirow{2}{*}{$\begin{array}{c}\text { Standardized } \\
\text { Coefficients } \\
\text { Beta }\end{array}$} & \multirow[b]{2}{*}{$\mathrm{t}$} & \multirow[b]{2}{*}{ Sig. } \\
\hline & $\mathrm{B}$ & Std. Error & & & \\
\hline $1 \quad$ (Constant) & 18.966 & 3.342 & & 5.674 & .000 \\
\hline Kualitas Produk (X3) & .515 & .087 & .519 & 5.887 & .000 \\
\hline
\end{tabular}

a. Dependent Variable: Purchasing Decisions (Y)

Based on the test results in the table above, the value of $t_{\text {count }}>t_{\text {table }}$ or $(5.887>1.986)$ is obtained, thus the hypothesis that there is a significant influence on the quality of the product on the purchasing decision is accepted. Hypothesis testing with the F test is used to find out which simultaneous hypotheses are accepted. 
8 | Jurnal Administrare: Jurnal Pemikiran Ilmiah dan Pendidikan Administrasi Perkantoran

Vol. 7, No. 1, January-June 2020, Pages 1-10

Table 14.

Hypothesis Test Results of Consumer Perception, Innovation and Product Quality on Purchasing Decisions.

ANOVA ${ }^{\mathbf{a}}$

\begin{tabular}{|c|c|c|c|c|c|c|}
\hline \multicolumn{2}{|c|}{ Model } & Sum of Squares & df & Mean Square & $\mathrm{F}$ & Sig. \\
\hline \multirow[t]{3}{*}{1} & Regression & 626.015 & 3 & 208.672 & 30.779 & $.000^{\mathrm{b}}$ \\
\hline & Residual & 623.725 & 92 & 6.780 & & \\
\hline & Total & 1249.740 & 95 & & & \\
\hline
\end{tabular}

a. Dependent Variable: Purchase Decision (Y)

b. Predictors: (Constant), Product Quality (X3), Innovation (X2), Consumer Perception (X1)

Based on the test results in the above table, the value of ${ }_{F c o u n t}>F_{\text {table }}$ or $(30.777>2,470)$ is obtained, thus the hypothesis proposed that there is a significant influence between consumer perception, innovation and product quality on purchasing decisions is accepted.

\section{CONCLUSION}

Based on the results of the study, consumer perceptions significantly influence purchasing decisions with a contribution of $31.9 \%$. Hypothesis testing obtained tcount $>t$ table or (6.632> 1.986). Innovation has a significant effect on purchasing decisions with an influence contribution of $41.4 \%$. Hypothesis testing obtained tcount> $t$ table or $(8,151>1,986)$. Product quality has a significant effect on purchasing decisions with a contribution of $26.9 \%$. Hypothesis testing obtained tcount> $t$ table or (5.887> 1.986). Consumer perception, innovation and product quality have a significant effect on purchasing decisions with a contribution of $50.1 \%$ while the remaining $49.9 \%$ are influenced by other factors. Hypothesis testing obtained value Fcount> F table or (30.777> 2.470).

\section{REFERENCES}

Chandra, Y. I. (2016). Perancangan Aplikasi Resep Makanan Tradisional Indonesia Menggunakan Pendekatan Agile Process Dengan Model Extreme Programming Berbasis Android. Seminar Nasional APTIKOM.

D'Antuono, L. F. (2015). Traditional Foods. In Encyclopedia of Food and Health. https://doi.org/10.1016/B978-0-12-384947-2.00700-5

Jackson, D. (2014). Bussiness graduate performance in oral communication skill. The International Journal of Management Education.

John L. Colley, J., Doyle, J. L., Hardie, R. D., Logan, G. W., \& Stettinius, W. (2007). Principles of General Management. In Association with the Darden Graduate School of Bussiness Administration. https://doi.org/10.1017/CBO9781107415324.004 
Kadji, J. (2015). Optimalisasi Tata Kelola Sektor Pariwisata di Kabupaten Gorontalo. Jurnal Ad'ministrare: Jurnal Pemikiran Ilmiah Dan Pendidikan Administrasi Perkantoran, 2(1), $1-15$.

Kotler dan Amstrong. (2008). Prinsip-Prinsip Pemasaran Jilid I. In Erlangga.

Lendel, V., Hittmár, Š., \& Siantová, E. (2015). Management of Innovation Processes in Company. Procedia Economics and Finance. https://doi.org/10.1016/s2212$5671(15) 00382-2$

Novicadisa, S., \& Sjamsuddin, S. (2016). Implementasi Kebijakan Pemungutan Pajak Hotel Kategori Rumah Kos Di Kota Malang. Jurnal Ilmiah Ilmu Administrasi Publik: Jurnal Pemikiran Dan Penelitian Administrasi Publik, 6(1), 69-76.

Prasodjo, T. (2017). Pengembangan Pariwisata Budaya dalam Perspektif Pelayanan Publik. Jurnal Office, 3(1), 7-12.

Rahmawaty, U., \& Maharani, Y. (2014). Pelestarian Budaya Indonesia Melalui Pembangunan. Jurnal Tingkat Sarjana Bidang Senirupa Dan Desain.

Sabana, S. (2007). Nilai Estetis Pada Kemasan Makanan Tradisional Yogyakarta. ITB Journal of Visual Art and Design. https://doi.org/10.5614/itbj.vad.2007.1.1.2

Said, F., Akib, H., Salam, R., \& Baharuddin, A. (2017). An Analysis of Tourism Visit Trend. 2nd International Conference on Education, Science, and Technology (ICEST 2017). Atlantis Press.

Samad, Y., Salim, M., Arfin, M., \& Akib, H. (2018). The Functions of Language in Realizing the Indonesian Culinary on the official tourism website of Indonesia: A Tourism Discourse Perspective. The Functions of Language in Realizing the Indonesian Culinary on the Official Tourism Website of Indonesia: A Tourism Discourse Perspective (October 31, 2018). Ewha Journal of Social Sciences, Forthcoming.

Sanjaya, W. (2008). Kurikulum Dan Pembelajaran (Teori \& Praktek KTSP).

Sanjaya, W. (2010). Strategi Pembelajaran Berorientasi Standar Proses Pendidikan. System.

Sanjaya, W. (2015). Perencanaan dan Desain Sistem Pembelajaran. Kencana,Prenadamedia Group.

Sims, R. (2009). Food, place and authenticity: Local food and the sustainable tourism experience. Journal of Sustainable Tourism. https://doi.org/10.1080/09669580802359293

Soliha, E. (2008). Analisis Industri Ritel di Indonesia. Jurnal Bisnis Dan Ekonomi (JBE).

Sunyoto, D. (2014). Dasar - Dasar Manajemen Pemasaran. In dasar dasar manajemen pemasaran.

Sutisna. (2003). Perilaku Konsumen: Teori dan penerapannya dalam Pemasaran. Ghalia Indonesia, Jakarta. https://doi.org/10.1007/BF01013984

Swastha, Basu, I. (2014). Manajemen Pemasaran Modern. In Liberty, Yogyakarta. https://doi.org/10.1017/CBO9781107415324.004 
10 Jurnal Administrare: Jurnal Pemikiran Ilmiah dan Pendidikan Administrasi Perkantoran Vol. 7, No. 1, January-June 2020, Pages 1-10

Tjiptono. (2007). Strategi Pemasaran, edisi kedua.

Uno, H. H. B. (2010). Model pembelajaran: menciptakan proses belajar mengajar yang kreatif dan efektif. In Jakarta: Bumi Aksara. https://doi.org/10.1038/cddis.2011.1

Wairooy, A. (2017). Pengaruh Disiplin Kerja dan Kompensasi Terhadap Kinerja Karyawan pada PT. Pertamina (Persero), Tbk. Pemasaran Region VII Makassar. Jurnal Ad'ministrare: Jurnal Pemikiran Ilmiah Dan Pendidikan Administrasi Perkantoran, 4(1), $15-24$.

Wibawa, B. M., Rahmawati, Y., \& Rainaldo, M. (2018). Analisis Industri Bisnis Jasa Online Ride Sharing di Indonesia. Esensi: Jurnal Bisnis Dan Manajemen. https://doi.org/10.15408/ess.v8i1.5739

Yusa, N. M., \& Suter, I. K. (2012). Kajian Pangan Tradisional Bali dalam Rangka Pengmbangannya Menjadi Produk Unggulan di Kabupaten Gianyar. Pangan Tradisional. 